\title{
Anatomy, histochemistry, and immunohistochemistry of the olfactory subsystems in mice
}

\author{
Arthur W. Barrios ${ }^{1}$, Gonzalo Núñez ${ }^{2}$, Pablo Sánchez Quinteiro ${ }^{1}$ and Ignacio Salazar ${ }^{1 *}$ \\ Unit of Anatomy and Embryology, Department of Anatomy and Animal Production, Faculty of Veterinary, University of Santiago de Compostela, Lugo, Spain \\ 2 ICT Department, Hospital Polusa, Lugo, Spain
}

\author{
Edited by: \\ Pablo Chamero, University of \\ Saarland, Germany \\ Reviewed by: \\ Alino Martinez-Marcos, Universidad \\ de Castilla, Spain \\ Carla Mucignat, University of \\ Padova, Italy \\ *Correspondence: \\ Ignacio Salazar, Unit of Anatomy and \\ Embryology, Department of \\ Anatomy and Animal Production, \\ Faculty of Veterinary, University of \\ Santiago de Compostela, Av. \\ Carballo Calero s/n, 27002 \\ Lugo, Spain \\ e-mail: ignacio.salazar@usc.es
}

The four regions of the murine nasal cavity featuring olfactory neurons were studied anatomically and by labeling with lectins and relevant antibodies with a view to establishing criteria for the identification of olfactory subsystems that are readily applicable to other mammals. In the main olfactory epithelium and the septal organ the olfactory sensory neurons (OSNs) are embedded in quasi-stratified columnar epithelium; vomeronasal OSNs are embedded in epithelium lining the medial interior wall of the vomeronasal duct and do not make contact with the mucosa of the main nasal cavity; and in Grüneberg's ganglion a small isolated population of OSNs lies adjacent to, but not within, the epithelium. With the exception of Grüneberg's ganglion, all the tissues expressing olfactory marker protein (OMP) (the above four nasal territories, the vomeronasal and main olfactory nerves, and the main and accessory olfactory bulbs) are also labeled by Lycopersicum esculentum agglutinin, while Ulex europaeus agglutinin I labels all and only tissues expressing $\mathrm{G}_{\text {ai2 }}$ (the apical sensory neurons of the vomeronasal organ, their axons, and their glomerular destinations in the anterior accessory olfactory bulb). These staining patterns of UEA-I and LEA may facilitate the characterization of olfactory anatomy in other species. A 710-section atlas of the anatomy of the murine nasal cavity has been made available on line.

Keywords: nasal cavity, morphology, digital atlas, olfactory epithelium, subdivisions, mouse

\section{INTRODUCTION}

Though between-species differences are notorious, the olfactory systems of mammals are in general able to recognize thousands of odorant molecules that vary in shape, size, charge, and function. These molecules are captured by the odorant receptors that populate the terminal dendritic trees of olfactory sensory neurons (OSNs) located in up to four areas of the epithelium lining the nasal cavities (Buck and Axel, 1991; Buck, 1996). The major such area is the main olfactory sensory epithelium (MOE) (Graziadei, 1971); the other nasal structures with OSN-bearing epithelium that may be present are the vomeronasal organ (VNO) (Jacobson, 1813; Doving and Trotier, 1998; Zancanaro, 2014), the septal organ (SO) (Broman, 1921; Rodolfo-Masera, 1943), and the ganglion of Grüneberg (GG) (Grüneberg, 1973). All these territories have been identified in mice (Breer et al., 2006; Storan and Key, 2006).

Of the four territories mentioned above, the GG was largely overlooked until its "rediscovery" a decade ago (Fuss et al., 2005; Koos and Fraser, 2005; Roppolo et al., 2006; Storan

\footnotetext{
Abbreviations: AOB, accessory olfactory bulb; Bn, Bouin fixative; Fr, buffered formalin fixative; GG, ganglion of Grüneberg; HE, haematoxylin-eosin; LEA, Lycopersicum esculentum agglutinin; MOB, main olfactory bulb; MOE, main olfactory epithelium; NBo, main olfactory nerve bundles; NBv, vomeronasal nerve bundles; OMP, olfactory marker protein; OR, olfactory receptor; OSbS, olfactory subsystems; OSNs, olfactory sensory neurons; $\mathrm{PB}$, phosphate buffer; SO, septal organ; TAARs, trace-amine-associated receptors; UEA-I, Ulex europaeus agglutinin I; $\mathrm{VNa}$, apical vomeronasal sensory epithelium; $\mathrm{VNb}$, basal vomeronasal sensory epithelium; VNO, vomeronasal organ; VNsE, vomeronasal sensory epithelium.
}

and Key, 2006), since when it has attracted considerable interest (Brechbühl et al., 2008; Schmid et al., 2010; Mamasuew et al., 2011; Matsuo et al., 2012). The other three have often been hypothesized as having distinct olfactory functions, an idea that in the case of the VNO and MOE is supported by the fact that whereas MOE OSNs project to the main olfactory bulb (MOB), the OSNs of the sensory epithelium of the VNO (the VNsE) project to the accessory olfactory bulb (AOB). Indeed, in both these cases more detailed correspondences have been distinguished: the apical and basal regions of the $\mathrm{VNsE}$ project to the anterior and posterior $\mathrm{AOB}$, respectively (Jia and Halpern, 1996; Salazar and Sánchez-Quinteiro, 2003), while four MOE zones have been reported to correspond to four MOB regions defined along an anterodorsomedial-caudoventrolateral axis (Ressler et al., 1993; Vassar et al., 1993). However, more exact MOE-MOB relationships are based on types of OSN rather than the MOE area they occupy (Munger et al., 2009; Ma, 2010; Mori and Sakano, 2011; Murthy, 2011); and, more importantly, the anatomical and functional independence of the vomeronasal and main olfactory systems is questioned by a number of findings (Boehm et al., 2005; Mandiyan et al., 2005; Yoon et al., 2005), notably the feedback from higher centers. Much remains to be known about the interactions of these two systems with each other (Keverne, 2005; Brennan and Zufall, 2006; Shepherd, 2006; Mucignat-Caretta et al., 2012) and with the GG and SO (Levai and Strotmann, 2003; Ma et al., 2003; Kaluza et al., 2004; Tian and Ma, 2008). 
In view of the above, the MOE, VNsE, SO and GG can be considered as the entry points of four olfactory subsystems (OSbS), the integration of which at higher levels has yet to be determined. To consolidate and possibly refine the structural basis of this approach in a way that would be readily applicable to other mammals, in the work described here we documented the morphology of the entire nasal cavity of the mouse and studied selected territories histochemically (using the lectins Ulex europaeus agglutinin-I and Lycopersicum esculentum agglutinin) and immunohistochemically [using antibodies against olfactory marker protein (OMP) and the G-protein subunits $\mathrm{G}_{\alpha \mathrm{i} 2}$ and $\mathrm{G}_{\alpha 0}$ ]. OMP is considered to be a marker of all olfactory neurons; $G_{\alpha i 2}$ and $G_{\alpha 0}$ differentiate vomeronasal OSNs projecting to different AOB territories (Wekesa and Anholt, 1999); and the two lectins used have coherent staining patterns in the olfactory bulbs (Salazar et al., 2001).

Our morphological material is available on-line as a 710-section digital atlas of the murine nasal cavity (see Supplementary Material below). As far as we know, this is the first time that the anatomies of all four olfactory territories have been presented together in relation to the cavity as a whole.

\section{MATERIALS AND METHODS ANIMALS}

Fourteen male or female healthy BALB/c mice aged at least 10 months, reared in the animal care facilities of the University of Santiago de Compostela (Registry No. 15003AE), were euthanized and decapitated in the Department of Pharmacology for use as control animals in pharmacological research; housing and handling followed the guidelines of the USC Biethical Committee. The intact heads were kindly donated to the authors.

\section{PROCESSING OF SAMPLES AND TISSUE SECTIONS}

Eight heads were fixed by immersion in $10 \%$ buffered formalin (Fr) and stored in 4\% Fr. The other six heads were fixed by immersion in Bouin's fixative (Bn), and after $24 \mathrm{~h}$ were transferred to $70 \%$ alcohol.

For examination of the entire nasal cavity, two Fr-fixed heads were decalcified in Shandon TBD-1 rapid decalcifier (Thermo, Pittsburgh, PA), oriented so that the hard palate was horizontal, embedded in paraffin wax, and cut in transverse sections $8-10 \mu \mathrm{m}$ thick perpendicular to the hard palate. Alternate sections (710) were transferred to slides and stained with haematoxylin-eosin (HE).

From two Fr- and two Bn-fixed heads, the brain was removed and transferred again to $\mathrm{Fr}$ or $\mathrm{Bn}$. The remaining pieces of the these heads, and the other eight heads (four Fr- and four Bn-fixed), were decalcified, oriented as above, and embedded, and serially cut transverse sections were transferred to slides. In the light of the information obtained from the entire nasal cavity series (see above), selected sections at seven different levels intersecting the GG, VNO, and SO, and at four levels of the posterior MOE, were stained with $\mathrm{HE}$, and the remainder were used in histochemical and immunohistochemical protocols.
Fr- and Bn-fixed olfactory bulbs were used as controls for the histochemical and immunohistochemical procedures described below.

\section{LECTIN HISTOCHEMISTRY}

The lectins Ulex europaeus agglutinin I (UEA-I) and Lycopersicum esculentum agglutinin (LEA) were obtained as biotin conjugates from Sigma (St. Louis, MO, USA). Tissue sections were (1) incubated for $30 \mathrm{~min}$ at room temperature with $2 \%$ bovine serum albumin in $0.1 \mathrm{M}$ phosphate buffer ( $\mathrm{PB}, \mathrm{pH} 7.2)$; (2) incubated for $24 \mathrm{~h}$ at $4^{\circ} \mathrm{C}$ with lectin at concentrations ranging from 20 to $60 \mu \mathrm{g} / \mathrm{mL}$ in $0.1 \mathrm{M}$ Tris buffer containing $0.5 \%$ bovine serum albumin; (3) washed for $2 \times 10 \mathrm{~min}$ in $\mathrm{PB}$; (4) incubated for $90 \mathrm{~min}$ at room temperature with Vectastain $\mathrm{ABC}$ reagent $(1: 250$ in $\mathrm{PB}$ ); and (5) incubated in $0.2 \mathrm{M}$ Tris- $\mathrm{HCl}$ buffer ( $\mathrm{pH} 7.6$ ) containing $0.05 \%$ 3,3-diaminobenzidine and $0.003 \% \mathrm{H}_{2} \mathrm{O}_{2}$. Controls were run without lectin or with preabsorption of lectin by an excess amount of the corresponding sugar.

\section{IMMUNOHISTOCHEMISTRY}

Immunohistochemical studies were performed using antibodies against olfactory marker protein (OMP) (Wako Chemicals, 1:500 dilution) and the G-proteins $\mathrm{G}_{\alpha \mathrm{i} 2}$ (Santa Cruz Biotechnology, 1:100) and $\mathrm{G}_{\alpha 0}$ (Santa Cruz Biotechnology and Medical \& Biological Lab Co., 1:100). Sections were dewaxed in xylene, rehydrated, and successively incubated (1) for $30 \mathrm{~min}$ at room temperature in $\mathrm{PB}$ containing 5\% normal horse serum and 2\% bovine serum albumin, (2) for $24 \mathrm{~h}$ at $4^{\circ} \mathrm{C}$ in primary antibody solution, (3) for $1 \mathrm{~h}$ in biotinylated secondary antibody solution, and (4) for $2 \mathrm{~h}$ in a solution of avidin-biotin-horseradish peroxidase complex (ABC Vectastain reagent); after which standard procedures for visualization of the horseradish peroxidase complex with 3,3-diaminobenzidine were followed, and the sections were dehydrated through alcohols, cleared in xylene, and coverslipped.

\section{IMAGE ACQUISITION AND PROCESSING}

Digital images were captured using a Karl Zeiss Axiocam MRc5 digital camera. When necessary, Adobe Photoshop CS4 (Adobe Systems, San Jose, CA) was used to adjust contrast and brightness to equilibrate light levels, and/or to crop, resize and rotate the images for presentation; no additional digital image manipulation was performed.

\section{IMPLEMENTATION OF THE ON-LINE ATLAS (SUPPLEMENTARY MATERIAL)}

The on-line atlas was developed using the languages HTML5, CSS3, JavaScript, PHP5 and XML, the libraries/frameworks JavaScript jQuery (v1.10.1) and Normalize.css (v2.1.3), and the scripts/plug-ins PhpThumb (v3.0), JQuery Sketch.js, Zoomooz (v1.1.6), ColorBox (v1.3.31), waitForImages, FitText (v1.1), qTip2 (v2.1.1), and Image Power Zoomer (v1.1). It consists of a front end comprising the content and associated functionality (accessible in any current web browser, including the latest versions of Mozilla Firefox, Google Chrome, Opera, Safari and Internet Explorer) and a back end PHP-based area for merging and managing the data, images and texts. 


\section{RESULTS}

\section{ANATOMY}

Figures 1A, 2 (see also the Supplementary Material) show the locations of the MOE, SO, VNO and GG, which occupy the mucosal lining of most of the nasal cavity except the ventral concha (for turbinate numbering, see Figures 1, 3).

The MOE features three major cell types: neurons, supporting cells, and the basal stem cells that generate olfactory neurons throughout life (Figure 4A). Three regions may be distinguished on the basis of whether the MOE tissue is locally, on average, (i) 3-5, (ii) 6-10, or (iii) 11 or more cells thick (Figures 4B-D, 5). In general, the MOE is thicker in dorsal regions than in the corresponding ventral regions, and there are similar thick-thin differences in the medial-lateral and posterior-anterior directions (see Supplementary Material).

The SO is an independent structure with the same characteristics as MOE region (i) (Figure 6A).

The VNO occupies a thin cylindrical lamina of bone located on the floor of the nasal cavity adjacent to the vomer. It comprises
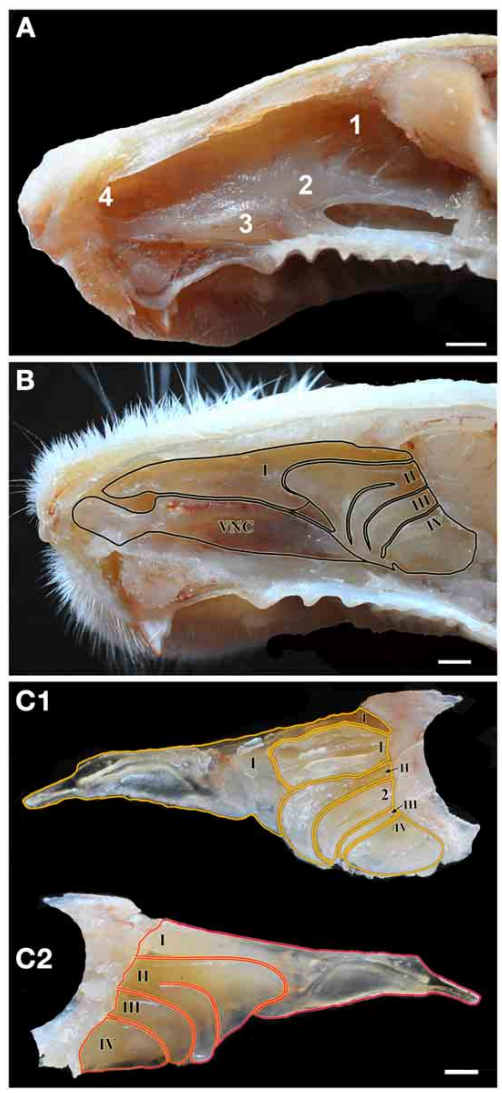

FIGURE 1 | Views of the nasal cavity. (A) The nasal septum, showing the location of the main olfactory epithelium (1), the septal organ (2), the vomeronasal organ (3) and Grüneberg's ganglion (4). (B) Medial view of the nasal conchae and ethmoturbinates following removal of the nasal septum, with endoturbinates numbered by Roman numerals (VNC, ventral nasal concha). (C) Lateral (C1) and medial (C2) views of the isolated dorsal nasal concha and ethmoturbninates, with ectoturbinates numbered by Arabic numerals and endoturbinates as in (B). Scale bars: (A) $2 \mathrm{~mm} ;(\mathbf{B}, \mathbf{C}) 1 \mathrm{~mm}$. the vomeronasal duct (a blind epithelial tube with a single small rostral orifice connecting it with the main nasal cavity) together with surrounding glands, vessels, nerves, and connective tissue. The VNsE is limited to the central levels of the medial wall of the duct (Figure 6B).
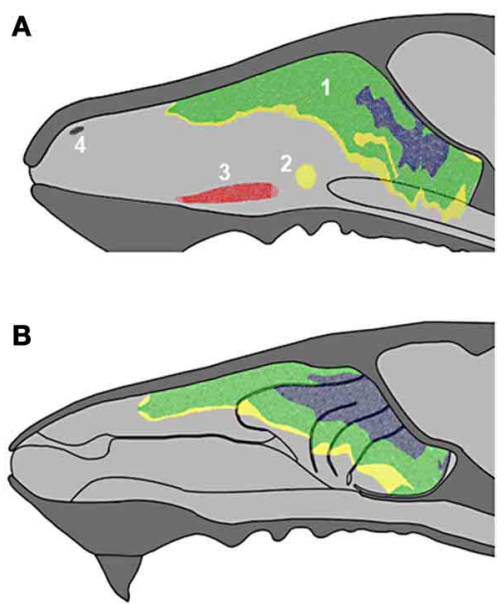

FIGURE 2 | Schematic drawings of the nasal septum $(A)$ and the medial aspect of the nasal cavity $(B)$, showing the locations of the main olfactory epithelium (1), septal organ (2), vomeronasal organ (3) and Grüneberg ganglion (4) with indication of epithelial thickness (yellow, thin; green, medium; blue, thick). See supplementary material.
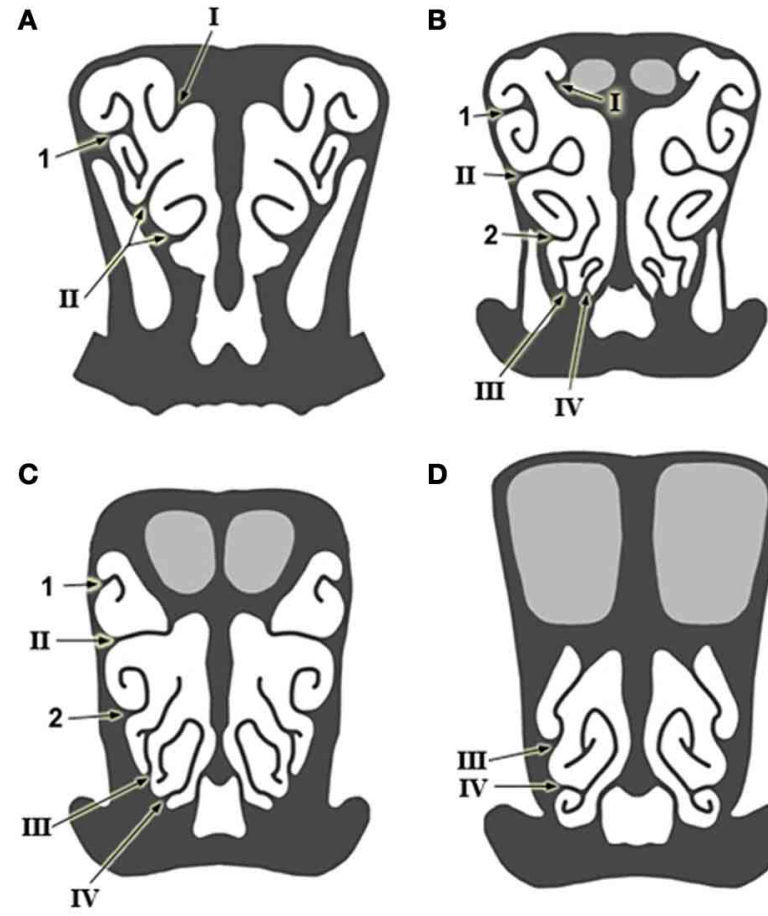

D

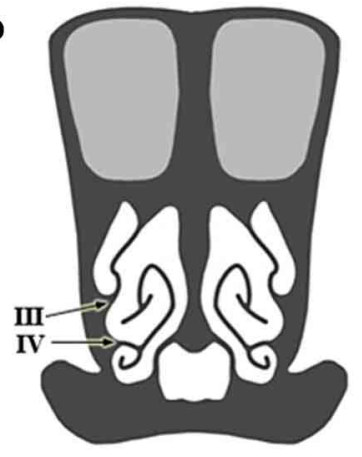

FIGURE 3 | Schematic drawings of transverse sections of the head, from anterior to posterior levels (A-D), showing the arrangement of the ethmoturbinates at several levels in the posterior part of the nasal cavity. Numbering as in Figure 1. 


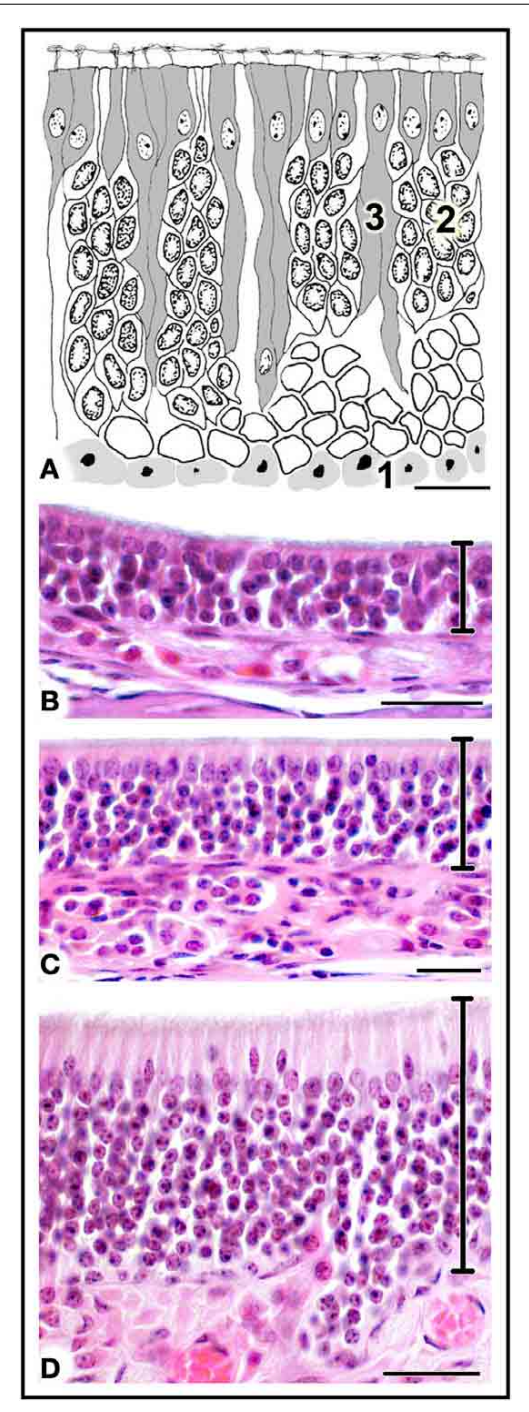

FIGURE 4 | (A) Diagrammatic reconstruction of main olfactory epithelium, showing basal cells (1), mature neurons (2) and supporting cells (3) (modified after Graziadei, 1971). (B,C) Haematoxylin-eosin-stained sections of areas of epithelium with different thicknesses (see text). Scale bars: (A) $10 \mu \mathrm{m}$; (B) $20 \mu \mathrm{m} ;$ (C,D) $25 \mu \mathrm{m}$.

In the GG, located in the nasal vestibule adjacent to the nasal septum and the dorsolateral nasal cartilage (Figure 6C), a small isolated group of OSNs are embedded in connective tissue under a dense network of blood vessels, adjoining but not within the epithelium. Among adult mice there is significant betweenindividual variation in GG anatomy; for example, symmetry between the right and left sides is not universal.

\section{HISTOCHEMISTRY AND IMMUNOHISTOCHEMISTRY Main olfactory epithelium}

We first applied all the histochemical and immunohistochemical stains to sections in which both main olfactory and vomeronasal nerves run adjacent to the septum. Though with different intensities, anti-OMP and LEA stained the MOE and both the main

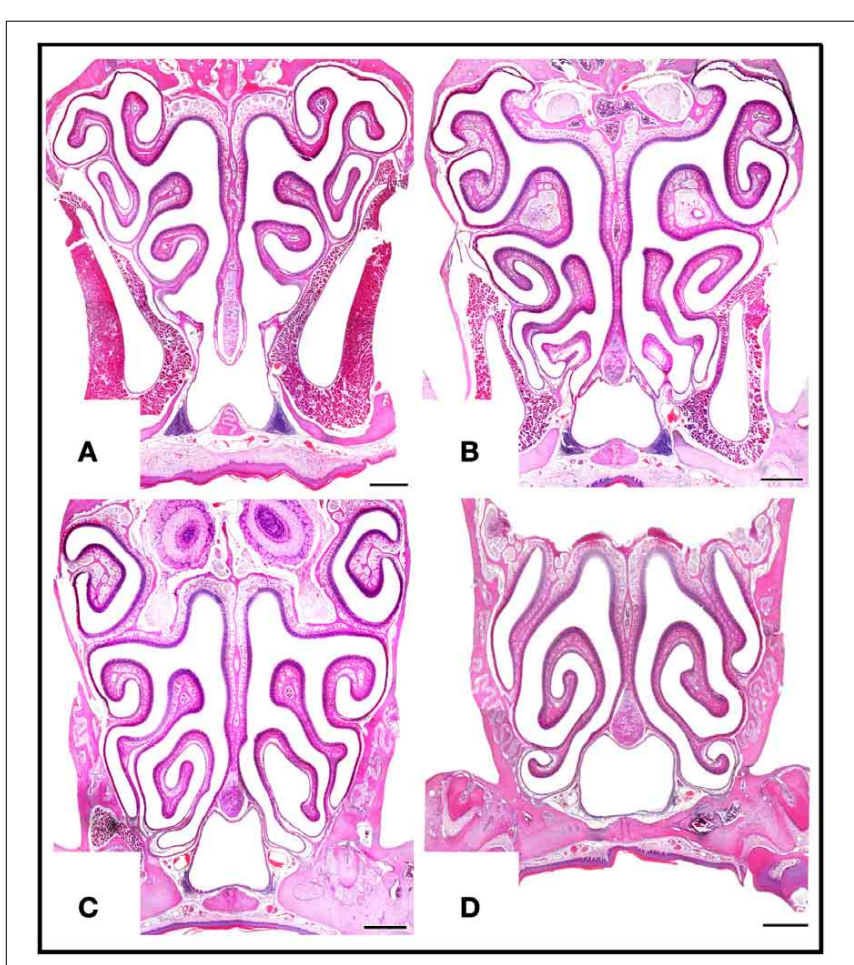

FIGURE 5 | Haematoxylin-eosin-stained transverse sections at four levels of the posterior nasal cavity, from anterior to posterior levels (A-D), where most of the MOE is located. Scale bars: $500 \mu \mathrm{m}$.

olfactory and vomeronasal nerves bundles (NBo and NBv, respectively); anti- $\mathrm{G}_{\alpha 0}$ strongly labeled all nerve bundles; and UEA-I and anti- $\mathrm{G}_{\alpha \mathrm{i} 2}$ bound only to $\mathrm{NBv}$ (Figure 7). The results of staining for OMP (Figure 8) and $\mathrm{G}_{\alpha 0}$ (Figure 9) at six different transverse levels of the nasal cavity were in agreement with these findings.

\section{Vomeronasal organ, septal organ, and the ganglion of Grüneberg}

The staining behavior of UEA-I, anti- $\mathrm{G}_{\alpha 0}$ and anti- $\mathrm{G}_{\alpha \mathrm{i} 2}$ in the VNsE distinguished apical and basal layers, UEA-I and anti- $\mathrm{G}_{\alpha \mathrm{i} 2}$ staining the apical VNsE (VNa), and anti- $\mathrm{G}_{\alpha 0}$ the basal VNsE $(\mathrm{VNb})$ (in this case mainly at the edges of the sensory epithelium) (Figures 10B,D,E). Anti-OMP and LEA stained both layers (Figures 10A,C). The staining pattern of the SO was essentially identical to that of the MOE (Figure 10F1 shows OMP positivity in an SO section). GG cells were also clearly OMP-positive, but accepted no other stain (Figure 10F2).

\section{Olfactory bulbs}

The staining patterns of the olfactory bulbs used as controls are shown in Figure 11. Note that like anti-OMP, LEA stains both the nervous and glomerular layers of both the MOB and the AOB.

\section{DISCUSSION}

The above results clearly identify four different olfactory sensory areas in the nasal cavities, and accordingly justify the use of OSbS terminology. In regard to the anatomy of the VNO, it is perhaps worth stressing that vomeronasal OSNs do not make 


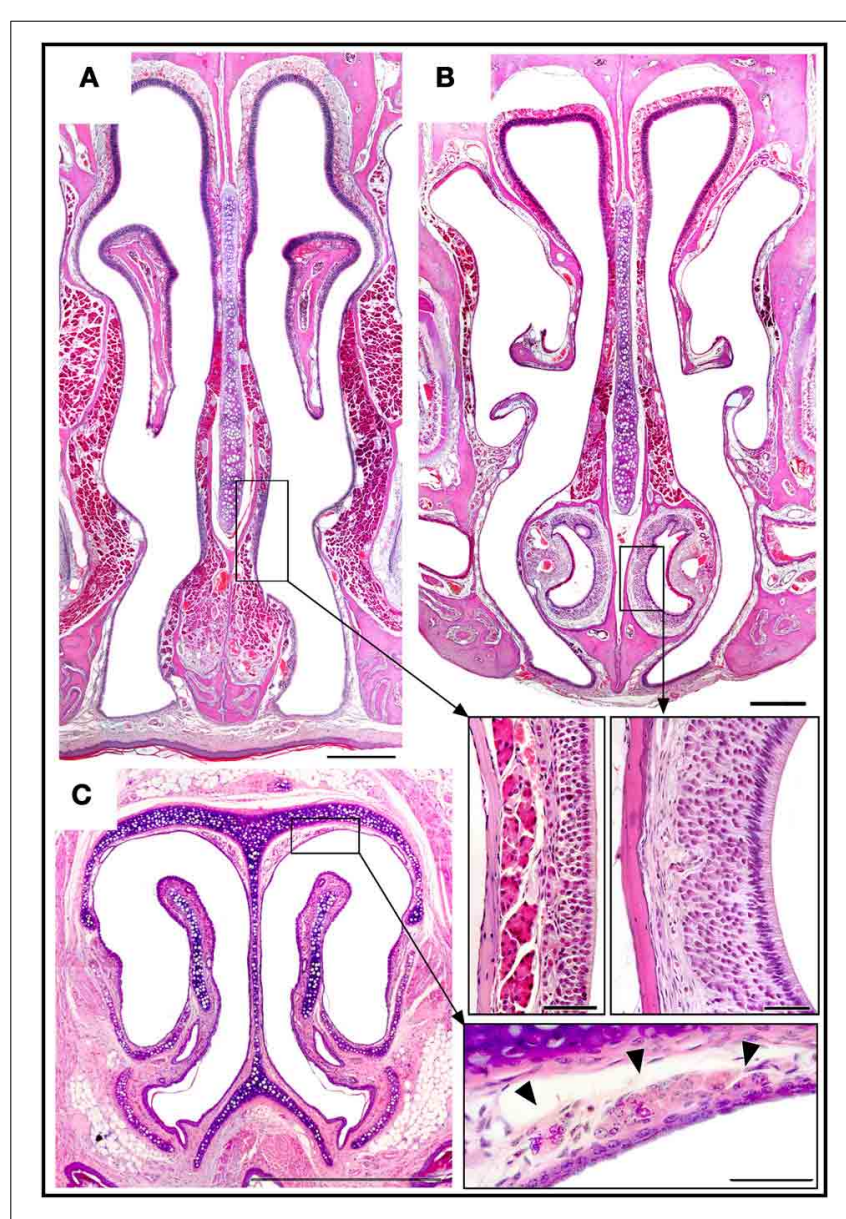

FIGURE 6 | Haematoxylin-eosin-stained transverse sections showing the locations of the septal organ (A), the vomeronasal organ (B), and Grüneberg's ganglion (C), together with an enlarged view of each in the corresponding inset. Topography of the rüneberg's ganglion cells (arrows heads). Scale bars: (A-C), $500 \mu \mathrm{m}$; insets, $50 \mu \mathrm{m}$.

contact with the mucosa of the main nasal cavity. For them to bind the semiochemicals to which they respond, these latter must therefore be pumped into the vomeronasal duct in some way, probably by vascular constriction (Meredith et al., 1980; Salazar et al., 2008). Thus, the non-epithelial components of the VNO do not merely provide mechanical and physiological support for the sensory epithelium, but must play an active role in olfaction. This raises a question as to the triggering of this pumping mechanism, which if vascular is presumably not of itself a voluntary action. One possibility is that it may be part of some general scentseeking behavioral pattern; another, that it may be triggered by the detection of an olfactory signal of broad significance by one of the three olfactory territories of the main nasal cavity.

The possibility of further defining subdivisions of the olfactory epithelial territories on the basis of the receptor types borne by OSNs appears to depend on both the OSbS and the broad class of receptor types in question. The VNsE is clearly divisible into an apical stratum with OSNs bearing receptors of type V1R, and a basal stratum with V2R-bearing OSNs (Wagner et al., 2006). The axons of these apical and basal strata respectively project to

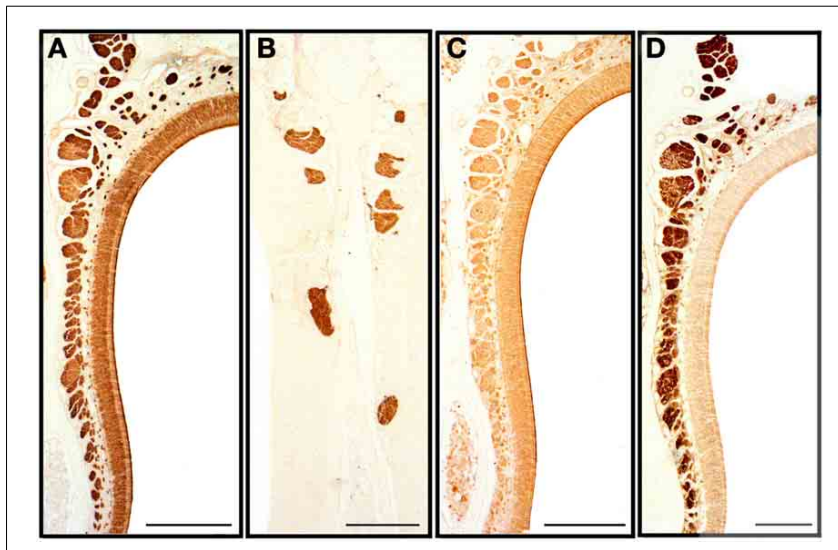

FIGURE 7 | Transverse sections of the nasal septum stained with anti-OMP (A), UEA-I (B), LEA (C) and anti-G $\mathrm{G}_{\alpha 0}$ (D), showing the olfactory sensory epithelium and the olfactory and vomeronasal nerve bundles. Scale bars: (A,C) $150 \mu \mathrm{m}$; (B,D) $100 \mu \mathrm{m}$.

the anterior and posterior regions of the AOB. Further, the upper and lower sublayers of the basal VNsE respectively project to the anterior and posterior parts of the posterior $\mathrm{AOB}$, in correlation with whether the V2R OSNs do not or do express H2-mv genes (Salazar and Sánchez-Quinteiro, 2003; Ishii and Mombaerts, 2008). However, these divisions appear to be crossed by OSNs bearing formyl peptide receptors, which seem to be widely dispersed in either the entire VNsE (Liberles et al., 2009) or, with a rostrocaudal gradient that is more pronounced in juveniles than adults, in its apical layer (Rivière et al., 2009; Dietschi et al., 2013). Moreover, the functional significance of these subdivisions is unknown, and its elucidation will require more extensive investigation of the ligands recognized by the vomeronasal system (Chamero et al., 2012; Francia et al., 2014).

In the MOE, the first reports of zonal organization of OSNs bearing the multiple varieties of "canonical" G-protein-coupled olfactory receptor (OR), made possible by the cloning of odorant receptor genes (Buck and Axel, 1991), spoke of each receptordefined OSN type being distributed at random in just one of three or four zones (Ressler et al., 1993; Vassar et al., 1993). Subsequently, a more refined scheme emerged that related to the distinction between phylogenetically older (class I) and younger (class II) OR types: while almost all OSNs with a class I OR type or belonging to a subset of class II OR types are randomly located in a dorsomedial region (D), each of the multiple other class II types is borne exclusively by OSNs occupying a typespecific antero-posterior swathe in the remainder of the MOE $(\mathrm{V})$, with the centerline of one swathe displaced dorsoventrally just slightly from that of the next, so that each swathe overlaps multiple others (Miyamichi et al., 2005). The projection of the OSNs defined by a given OR type to just a single pair of MOB glomeruli, confirmed by experiments with P2-IRES-taulacZ mice (Mombaerts et al., 1996), makes the detailed map of the MOE in the MOB discrete (Luo and Flanagan, 2007), but this map nevertheless respects the zonal organization described above: OR OSNs in MOE region D project to the dorsal MOB (Kobayakawa et al., 2007; Bozza et al., 2009), and the dorsoventral 


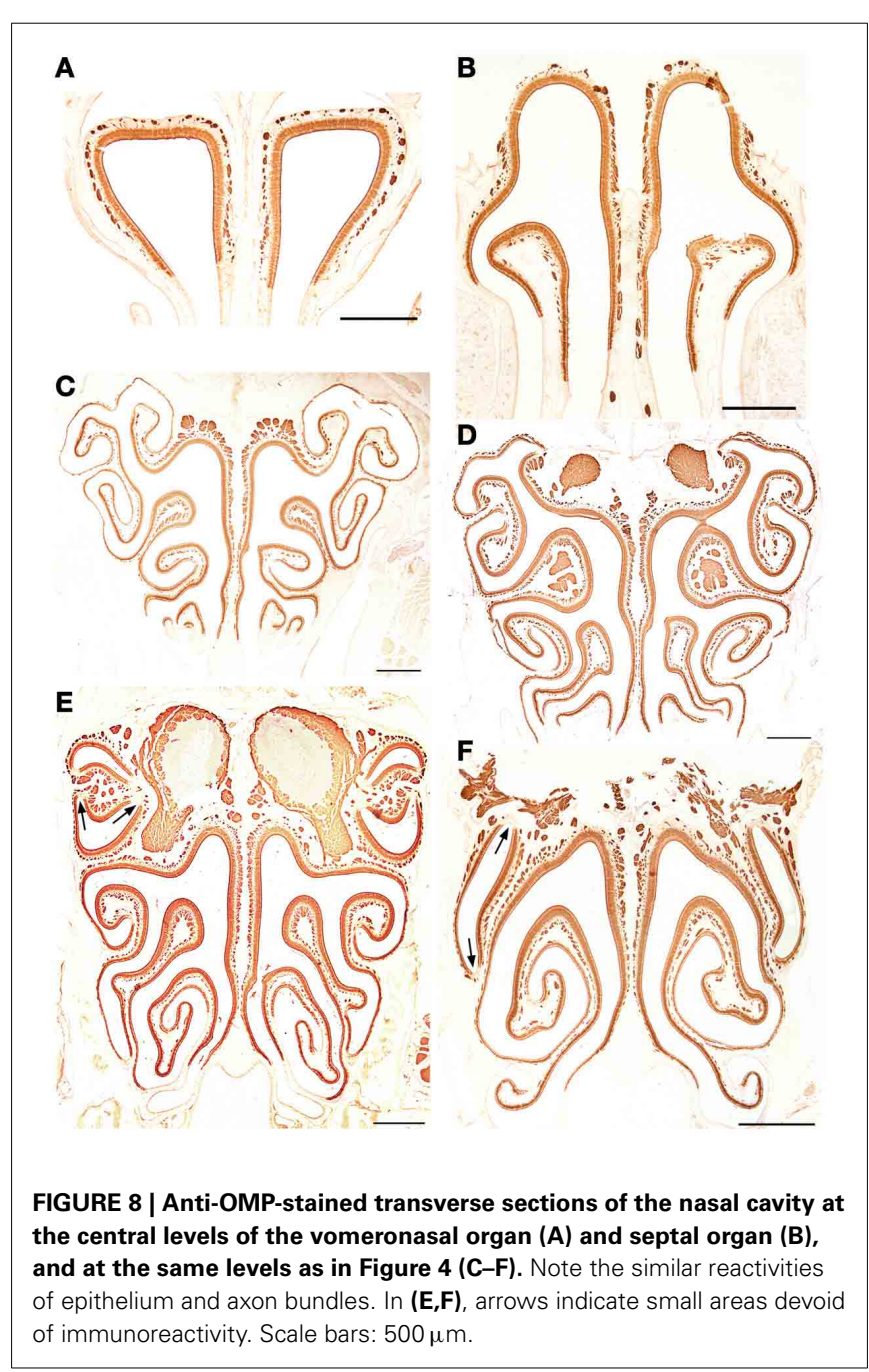

order of OR types in region $\mathrm{V}$ is faithfully reproduced by the glomeruli to which their OSNs project in the ventral MOB. Also, the more recently discovered subset of OR OSNs that express TRPM5, which are mainly located in the ventrolateral MOE, mainly project to glomeruli in the ventral MOB (Lin et al., 2007); and a similar degree of topographical correspondence is seen in regard to OSNs bearing trace-amine-associated receptors (TAARs, one of the two known types of non-OR olfactory receptor in the MOE; Liberles and Buck, 2006), TAAR OSNs located in the dorsal MOE projecting to two or three glomeruli in a welldefined dorsal area of the MOB (Pacifico et al., 2012). However, topographicness is less evident in the mapping of OSNs with guanylyl cyclase D receptors, the other non-OR MOE receptor type. These OSNs, which are found in clusters in a limited MOE zone (mostly in the dorsal recesses of the nasal cavity), project to a number of the "necklace glomeruli" surrounding the caudal end of the MOB (Gibson and Garbers, 2000; Walz et al., 2007).

In the present study we found that the MOE is in general thicker in the dorsal zone than the ventral, thicker in the medial zone than the lateral, and thicker in the posterior zone than

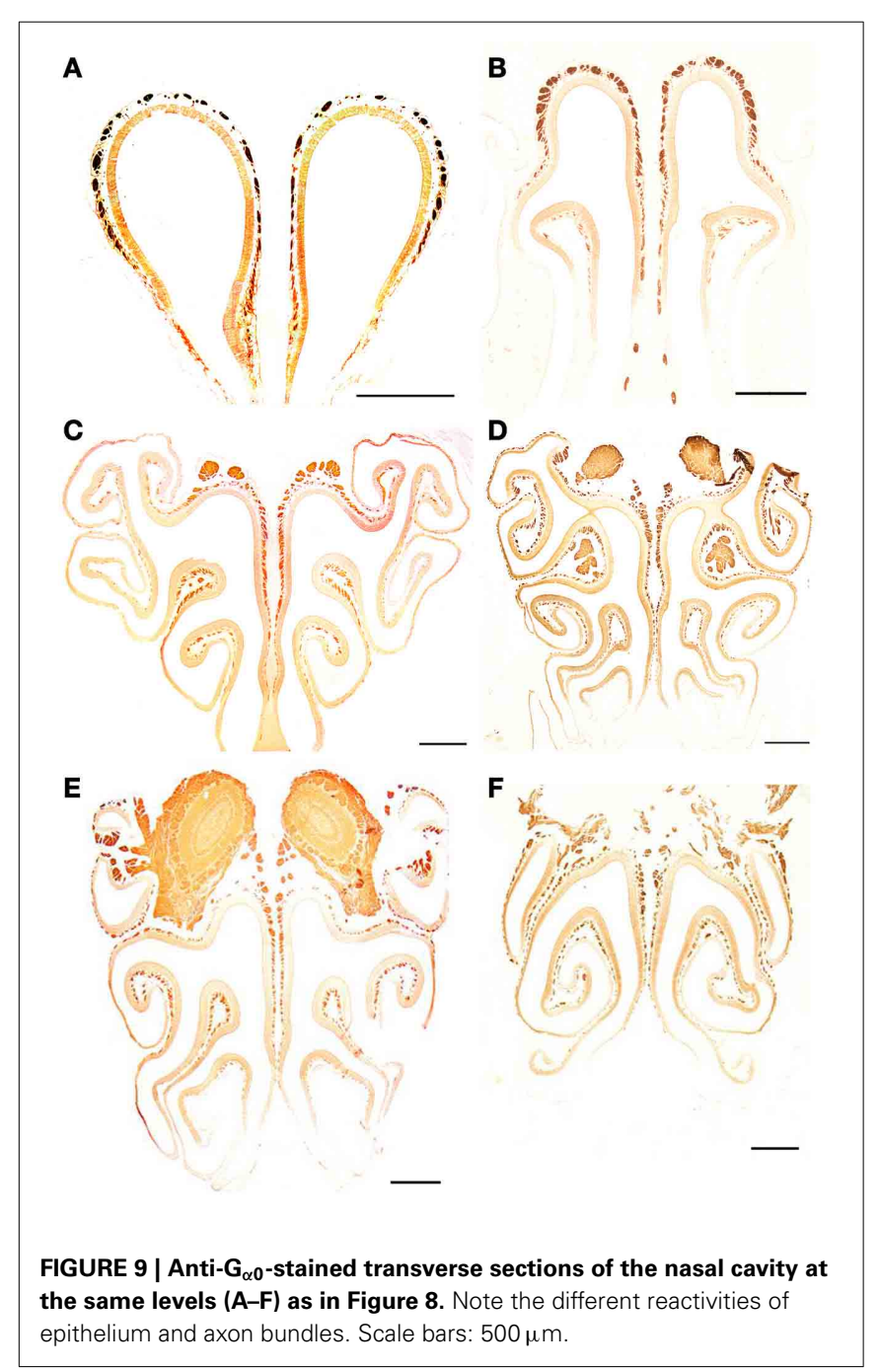

the anterior. The relevance of these findings to the zonal organization described above is unclear, but they should be taken into account in future work, among other reasons because they are consistent with inspiratory airflow paths (Schoenfeld and Cleland, 2005).

The olfactory bulbs were initially included in this study merely as control tissues, since in previous work they have reacted very well with the lectins employed in the present study, exhibiting consistent, anatomically coherent patterns: although staining uniformity depends upon the age of the animal (Salazar and Sánchez-Quinteiro, 2003), LEA labels the glomeruli and incoming nerves of both the $\mathrm{AOB}$ and the $\mathrm{MOB}$, while UEA-I binds only to the vomeronasal nerves and AOB structures (Salazar et al., 2001). Our present results confirm these findings and extend them to the corresponding sensory epithelia. UEA-I thus emulates anti- $\mathrm{G}_{\alpha \mathrm{i} 2}$ in its specificity (under the conditions of this study) for the olfactory subsystem entered via the apical VNsE; while LEA, except for its failure to stain the Grüneberg ganglion, emulates the neuron-staining behavior of anti-OMP, which is specific for the olfactory nervous system as a whole (Margolis, 1972) (in Figures 8E,F, note the absence of stain in acute angles 


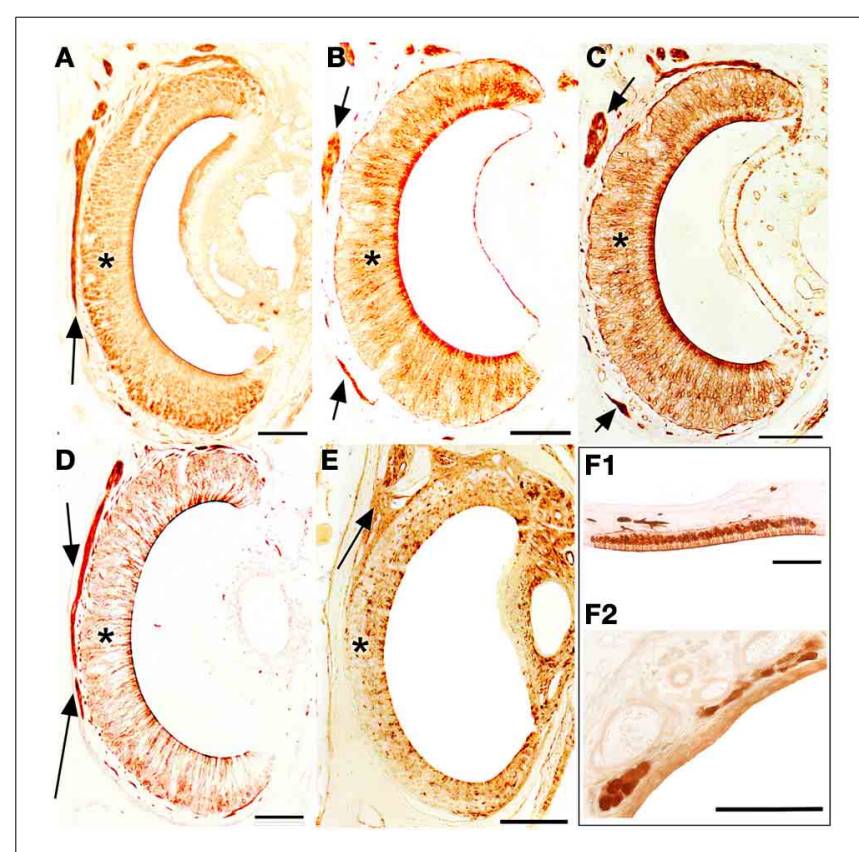

FIGURE 10 | Transverse sections of the vomeronasal duct stained with anti-OMP (A), UEA-I (B), LEA (C), anti-G , $_{\alpha 0}$ (D) and anti-G $\mathrm{G}_{\alpha i 2}(\mathrm{E})$, and of the septal organ $\left(F_{1}\right)$ and Grüneberg ganglion $\left(F_{2}\right)$ stained with anti-OMP. Arrows indicate vomeronasal nerve axons medial to the vomeronasal sensory epithelium (asterisk). Scale bars: $100 \mu \mathrm{m}$.

of the turbinates, where neural cells are lacking; Suzuki et al., 2000). Although LEA, unlike anti-OMP, also stains glands, vessels and other tissues adjoining neurons, and is also prone to non-specific staining, this mimicry of anti-OMP by LEA and of anti-G $\mathrm{G}_{\alpha \mathrm{i} 2}$ by UEA-I, which is also found in a number of other species (see Salazar and Sánchez-Quinteiro, 2009), allows the use of these inexpensive lectins to obtain prima facie evidence concerning the structure of the VNsE in hitherto unstudied species. Although the molecular basis of this mimicry, i.e., the identity of the sugar-bearing molecules to which UEA-I and LEA bind in the olfactory system, is not totally clear, it appears to involve the role of cell surface blood group antigens in the wiring of the olfactory system (see, for example, St John et al., 2006).

In this study, neither UEA-I nor anti- $\mathrm{G}_{\alpha \mathrm{i} 2}$ bound to the MOE, the septal organ, or Grüneberg's ganglion. The absence of binding to the MOE appears to contradict a report that $\mathrm{G}_{\alpha \mathrm{i} 2}$ is expressed in olfactory neurons located near the dorsal septum and in the dorsal recess of the nasal cavity, and in MOB glomeruli concentrated mainly on the medial side (Wekesa and Anholt, 1999); it seems possible that the neurons stained by Wekesa and Anholt in the nasal cavity may have been vomeronasal nerves, although this would not explain their observations in the MOB. Our results are in keeping with those of Wekesa and Anholt (1999) in that expression of $\mathrm{G}_{\alpha o}$ was restricted to the basal VNsE and to the glomeruli and incoming axons of the MOB and posterior AOB. That Grüneberg's ganglion was stained by anti-OMP but by neither anti- $\mathrm{G}_{\alpha o}$ nor anti- $\mathrm{G}_{\alpha \mathrm{i} 2}$ is in keeping with the findings of Roppolo et al. (2006), who observed mRNA for OMP but not
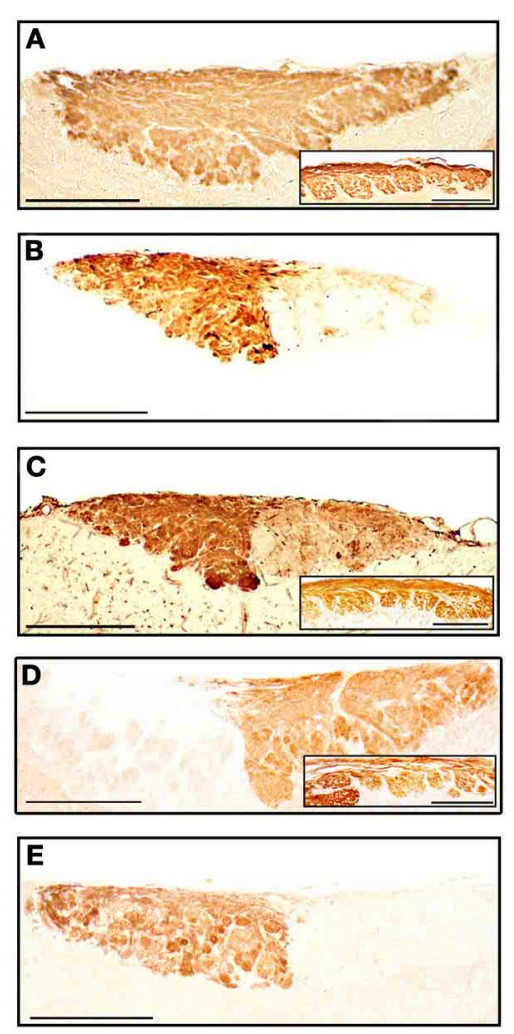

FIGURE 11 | Parasagittal sections of the olfactory bulb through the AOB (left anterior, right posterior) stained with anti-OMP (A), UEA-I (B), LEA (C), anti-G $\mathbf{G}_{\alpha \mathbf{0}}$ (D) and anti-G $\mathbf{G}_{\alpha \mathbf{i} \mathbf{2}}$ (E). Insets show the nervous and glomerular layers of the MOB. Scale bars: (A) $250 \mu \mathrm{m}$; (B-E) and insets, $200 \mu \mathrm{m}$.

for then known ORs, V1Rs or V2Rs, but not with studies that have detected several TAARs (Fleischer et al., 2007) and the novel vomeronasal receptor V2r83 (Fleischer et al., 2006), which is apparently co-expressed with the guanylyl cyclase GC-G (Matsuo et al., 2012).

\section{CONCLUDING REMARKS}

The discovery of novel genes involved in the initial stages of olfaction has renewed interest in this sensory system, which is evidently more complex than was previously imagined. Even at the grossest level, it is clear that any division into subsystems must define more than just the main and accessory olfactory systems, and at least three sets of criteria are available for refinement of this earlier conception: (i) division into four subsystems in accordance with the four spatially separated areas of sensory epithelium (MOE, SO, VNsE, and GG); (ii) division as above together with further division in accordance with axon targets, giving six subsystems (MOE OSNs projecting to necklace glomeruli, MOE OSNs projecting to non-necklace glomeruli, the SO, apical VNsE OSNs, basal VNsE OSNs, and GG); (iii) division of OSNs in accordance with their receptor type (which affords subsystems with epithelial domains that are both overlapping and fragmented, but is nevertheless a feasible option). However, there is an often overlooked problem in that the more complex 
Table 1 | Summarizes the histochemical and immunohistochemical results.

\begin{tabular}{llllll}
\hline & OMP & UEA-I & LEA & G $\alpha \mathbf{0}$ & G $\alpha \mathbf{i 2}$ \\
\hline $\mathrm{GG}$ & + & - & - & - & - \\
$\mathrm{VNa}$ & + & + & + & - & + \\
$\mathrm{VNb}$ & + & - & + & + & - \\
$\mathrm{SO}$ & + & - & + & - & - \\
$\mathrm{MOE}$ & + & + & + & - & - \\
$\mathrm{NBv}$ & + & - & + & + & + \\
$\mathrm{NBO}$ & + & + & + & - & + \\
$\mathrm{AOBa}$ & + & - & + & + & - \\
$\mathrm{AOBp}$ & + & - & + & + \\
$\mathrm{MOB}$ & + & & + & + & - \\
\end{tabular}

Reactivities of the Grüneberg ganglion (GG), apical vomeronasal sensory epithelium (VNa), basal vomeronasal sensory epithelium (VNb), septal organ (SO), main olfactory epithelium (MOE), vomeronasal nerve bundles (NBV), main olfactory nerve bundles (NBo), anterior accessory olfactory bulb (AOBa), posterior accessory olfactory bulb (AOBP) and main olfactory bulb (MOB) with anti-OMP, UEA-I, $L E A$, anti- $G_{\alpha o}$ and anti- $G_{\alpha i 2}$

the classification, the more difficult it will be to corroborate in larger species (e.g., if criteria require examination of transgenic animals), and the more difficult it will be to adapt to species with olfactory abilities differing from those of mice (Salazar and Sánchez-Quinteiro, 2009).

We suggest that the five-subsystem classification implicit in Table 1 (MOE-NBo-MOB, SO, VNa-NBv-AOBa, VNb-NBvAOBp, GG) constitutes a basic scheme, the validity of which for any other species can be easily investigated by the methods described in this paper, and which if necessary can be easily adapted in accordance with the results of these procedures. Although there is no doubt that progress in our understanding of the sense of smell will continue to be driven by molecular-genetic approaches (Axel, 2005), it is equally unquestionable that such studies should be consistent with the anatomy of the explored region (Schoenfeld and Cleland, 2005).

\section{AUTHOR CONTRIBUTIONS}

Ignacio Salazar designed the research and wrote the paper. Arthur W. Barrios, Gonzalo Núñez and Pablo Sánchez Quinteiro performed the work. Arthur W. Barrios Barrios, Gonzalo Núñez, Pablo Sánchez Quinteiro and Ignacio Salazar analyzed and discussed the data.

\section{ACKNOWLEDGMENTS}

We thank N. Vandenberghe and D. Salazar for intellectual support and helpful comments; L. Botana and A. Alonso for kindly providing mice; A. Outeiro and J. Castiñeira for technical assistance; and I.C. Coleman for revising the final English version. WAB thanks the Spanish Ministry of Foreign Affairs and Cooperation for an AECID grant. Private financial support is gratefully acknowledged. We apologize to the authors whose works have contributed to this field and could not be cited here.

\section{SUPPLEMENTARY MATERIAL}

The on-line atlas of the murine nasal cavity associated with this manuscript as Supplementary Material is available at http:// www.usc.es/anatembriol/. It comprises transverse sections of the whole nasal cavity organized in thirty-five 20-section segments and a final 10-section segment. Clicking on Views and then on Analysis shows, superimposed on a lateral view of the nasal cavity, a grid defining the 31 transverse segments. Clicking on a segment opens a window with thumbnails of its 10 or 20 numbered sections; clicking on a thumbnail brings up the section. The GG is located in segments 4 and 5 (sections 0522-0626), the VNO in segments 12-20 (sections 1511-2416), the SO in segments 21-23 (sections 2531-2724), and the MOE in segments 12-35 (sections 1421-4621). The turbinates are located as follows: the dorsal nasal concha and endoturbinate $I$ in segments $12-30$ (sections 1421-3812), endoturbinate II in segments 20-31 (sections 2412-3926), endoturbinate III in segments 26-32 (sections 3031-4126), endoturbinate IV in segments 28-35 (sections 34214621), ectoturbinate 1 in segments 23-31 (sections 2733-3923), and ectoturbinate 2 in segments 26-31 (sections 3114-4016). Yellow indicates MOE with 3-5 rows of cells, green 6-10 rows, and blue 11 or more rows (see also Figure 2).

\section{REFERENCES}

Axel, R. (2005). Scents and sensibility: a molecular logic of olfactory perception (Nobel lecture). Angew. Chem. Int. Ed. Engl. 44, 6110-6127. doi: 10.1002/anie. 200501726

Boehm, U., Zou, Z., and Buck, L. B. (2005). Feedback loops link odor and pheromone signaling with reproduction. Cell 123, 683-695. doi: 10.1016/j.cell.2005.09.027

Bozza, T., Vassalli, A., Fuss, S., Zhang, J. J., Weiland, B., Pacifico, R., et al. (2009). Mapping of class I and class II odorant receptors to glomerular domains by two distinct types of olfactory sensory neurons in the mouse. Neuron 61, 220-233. doi: 10.1016/j.neuron.2008.11.010

Brechbühl, J., Klaey, M., and Broillet, M. C. (2008). Grüneberg ganglion cells mediate alarm pheromone detection in mice. Science 321, 1092-1095. doi: $10.1126 /$ science. 1160770

Breer, H., Fleischer, J., and Strotmann, J. (2006). The sense of smell: multiple olfactory subsystems. Cell. Mol. Life Sci. 63, 1465-1475. doi 10.1007/s00018006-6108-5

Brennan, P. A., and Zufall, F. (2006). Pheromonal communication in vertebrates. Nature 444, 308-315. doi: 10.1038/nature05404

Broman, I. (1921). Über die Entwicklung der konstanten grösseren Nasennebenhöhlendrüsen der Nagetiere. Z. Anat. Entwickl. Gesch. 60, 439-586. doi: 10.1007/BF02593654

Buck, L. (1996). Information coding in the vertebrate olfactory system. Annu. Rev. Neurosci. 19, 517-544. doi: 10.1146/annurev.ne.19.030196.002505

Buck, L., and Axel, R. (1991). A novel multigene family may encode odorant receptors: a molecular basis for odor recognition. Cell 65, 175-187. doi: 10.1016/0092-8674(91)90418-X

Chamero, P., Leinders-Zufall, T., and Zufall, F. (2012). From genes to social communication: molecular sensing by the vomeronasal organ. Trends Neurosci. 35, 597-606. doi: 10.1016/j.tins.2012.04.011

Dietschi, Q., Assens, A., Challet, L., Carleton, A., and Rodriguez, I. (2013). Convergence of FPR-rs3-expressing neurons in the mouse accessory olfactory bulb. Mol. Cell. Neurosci. 56, 140-147. doi: 10.1016/j.mcn.2013.04.008

Doving, K. B., and Trotier, D. (1998). Structure and function of the vomeronasal organ. J. Exp. Biol. 201, 2913-2925.

Fleischer, J., Schwarzenbacher, K., Besser, S., Hass, N., and Breer, H. (2006). Olfactory receptors and signalling elements in the Grueneberg ganglion. J. Neurochem. 98, 543-554. doi: 10.1111/j.1471-4159.2006.03894.x

Fleischer, J., Schwarzenbacher, K., and Breer, H. (2007). Expression of trace amineassociated receptors in the Grueneberg ganglion. Chem. Senses 32, 623-631. doi: 10.1093/chemse/bjm032 
Francia, S., Pifferi, S., Menini, A., and Tirindelli, R. (2014). "Vomeronasal receptors and signal transduction in the vomeronasal organ of mammals," in Neurobiology of Chemical Communication, Chapter 10, ed C. Mucignat-Caretta (Boca Raton, FL: CRC Press), 297-324. doi: 10.1201/b16511-11

Fuss, S. H., Omura, M., and Mombaerts, P. (2005). The Grüneberg ganglion of the mouse projects axons to glomeruli in the olfactory bulb. Eur. J. Neurosci. 22, 2649-2654. doi: 10.1111/j.1460-9568.2005.04468.x

Gibson, A. D., and Garbers, D. L. (2000). Guanylyl cyclases as a family of putative odorant receptors. Annu. Rev. Neurosci. 23, 417-439. doi: 10.1146/annurev.neuro.23.1.417

Graziadei, P. P. P. (1971). "The olfactory mucosa of vertebrates", in Handbook of Sensory Physiology. Vol. IV. Chemical Senses 1, Olfaction, ed L. M. Beidler (Berlin: Springer-Verlag), 27-58.

Grüneberg, H. (1973). A ganglion probably belonging to the N. terminalis system in the nasal mucosa of the mouse. Z. Anat. Entwicklungsgesch. 140, 39-52. doi: 10.1007/BF00520716

Ishii, T., and Mombaerts, P. (2008). Expression of nonclassical class I major histocompatibility genes defines a tripartite organization of the mouse vomeronasal system. J. Neurosci. 28, 2332-2341. doi: 10.1523/JNEUROSCI.4807-07.2008

Jacobson, L. (1813). Anatomisk beskrivelse over et nyt organ I huusdyrenes nase. Vet-Selskapets Skrifter 2, 209-246.

Jia, C., and Halpern, M. (1996). Subclasses of vomeronasal receptor neurons: differential expression of $\mathrm{G}$ proteins (Gi2a and Goa) and segregated projections to the accessory olfactory bulb. Brain Res. 719, 117-128. doi: 10.1016/00068993(96)00110-2

Kaluza, J. F., Gussing, F., Bohm, S., Breer, H., and Strotmann, J. (2004). Olfactory receptors in the mouse septal organ. J. Neurosci. Res. 76, 442-452. doi: 10.1002/jnr.20083

Keverne, E. B. (2005). Odor here, odor there: chemosensation and reproductive function. Nature Neurosci. 8, 1637-1638. doi: 10.1038/nn1205-1637

Kobayakawa, K., Kobayakawa, R., Matsumoto, H., Oka, Y., Imai, T., Ikawa, M., et al. (2007). Innate versus learned odour processing in the mouse olfactory bulb. Nature 450, 503-508. doi: 10.1038/nature06281

Koos, D. S., and Fraser, S. E. (2005). The Grueneberg ganglion projects to the olfactory bulb. Neuroreport 16, 1929-1932. doi: 10.1097/01.wnr.0000186597. 72081.10

Levai, O., and Strotmann, J. (2003). Projection pattern of nerve fibres from the septal organ: Dil-tracing studies with transgenic OMP mice. Histochem. Cell Biol. 120, 483-492. doi: 10.1007/s00418-003-0594-4

Liberles, S. D., and Buck, L. B. (2006). A second class of chemosensory receptors in the olfactory epithelium. Nature 442, 645-650. doi: 10.1038/nature 05066

Liberles, S. D., Horowitz, L. F., Kuang, D., Contos, J. J., Wilson, K. L., SiltbergLiberles, J., et al. (2009). Formyl peptide receptors are candidate chemosensory receptors in the vomeronasal organ. Proc. Natl. Acad. Sci. U.S.A. 106, 9842-9847. doi: 10.1073/pnas.0904464106

Lin, W., Margolskee, R., Donnert, G., Hell, S. W., and Restrepo, D. (2007). Olfactory neurons expressing transient receptor potential channel M5 (TRPM5) are involved in sensing semiochemicals. Proc. Natl. Acad. Sci. U.S.A. 104, 2471-2476. doi: 10.1073/pnas.0610201104

Luo, L., and Flanagan, J. G. (2007). Development of continuous and discrete neural maps. Neuron 56, 284-300. doi: 10.1016/j.neuron.2007.10.014

Ma, M. (2010). "Multiple olfactory subsystems convey various sensory signals," in The Neurobiology of Olfaction, Chapter 9, ed A. Menini (Boca Raton, FL: CRC Press), 225-240. doi: 10.1201/9781420071993-c9

Ma, M., Grosmaitre, X., Iwema, C. L., Baker, H., Greer, C. A., and Shepherd, G. M. (2003). Olfactory signal transduction in the mouse septal organ. J. Neurosci. 23, $317-324$.

Mamasuew, K., Hofmann, N., Breer, H., and Fleischer, J. (2011). Grüneberg ganglion neurons are activated by a defined set of odorants. Chem. Senses 28, 271-282. doi: 10.1093/chemse/bjq124

Mandiyan, V. S., Coats, J. K., and Shah, N. M. (2005). Deficits in sexual and aggressive behaviors in Cnga2 mutant mice. Nature Neurosci. 8, 1660-1662. doi: $10.1038 / \mathrm{nn} 1589$

Margolis, F. L. (1972). A brain protein unique to the olfactory bulb. Proc. Natl. Acad. Sci. U.S.A. 69, 1221-1224. doi: 10.1073/pnas.69.5.1221

Matsuo, T., Rossier, D. A., Kan, C., and Rodriguez, I. (2012). The wiring of Grueneberg ganglion axons is dependent on neuropilin 1. Development 139, 2783-2791. doi: 10.1242/dev.077008
Meredith, M., Marques, D. M., O’Connell, R. J., and Stern, F. L. (1980). Vomeronasal pump: significance for male hamster sexual behavior. Science 207, 1224-1226.

Miyamichi, K., Serizawa, S., Kimura, H. M., and Sakano, H. (2005). Continuous and overlapping expression domains of odorant receptor genes in the olfactory epithelium determine the dorsal/ventral positioning of glomeruli in the olfactory bulb. J. Neurosci. 25, 3586-3592. doi: 10.1523/JNEUROSCI.032405.2005

Mombaerts, P., Wang, F., Dulac, C., Chao, S. K., Nemes, A., Mendelsohn, M., et al. (1996). Visualizing an olfactory sensory map. Cell 87, 675-686. doi: 10.1016/S0092-8674(00)81387-2

Mori, K., and Sakano, H. (2011). How is the olfactory map formed and interpreted in the mammalian brain? Annu. Rev. Neurosci. 34, 467-499. doi: 10.1146/annurev-neuro-112210-112917

Mucignat-Caretta, C., Redaelli, M., and Caretta, A. (2012). One nose, one brain: contribution of the main and accessory olfactory system to chemosensation. Front. Neuroanat. 6:46. doi: 10.3389/fnana.2012.00046

Munger, S. D., Leinders-Zufall, T., and Zufall, F. (2009). Subsystem organization of the mammalian sense of smell. Annu. Rev. Physiol. 71, 115-140. doi: 10.1146/annurev.physiol.70.113006.100608

Murthy, V. N. (2011). Olfactory maps in the brain. Annu. Rev. Neurosci. 34, 233-258. doi: 10.1146/annurev-neuro-061010-113738

Pacifico, R., Dewan, A., Cawley, D., Guo, C., and Bozza, T. (2012). An olfactory subsystem that mediates high-sensitivity detection of volatile amines. Cell Rep. 2, 76-88. doi: 10.1016/j.celrep.2012.06.006

Ressler, K. J., Sullivan, S. L., and Buck, L. B. (1993). A zonal organization of odorant receptor gene expression in the olfactory epithelium. Cell 73, 597-609. doi: 10.1016/0092-8674(93)90145-G

Rivière, S., Challet, L., Fluegge, D., Spehr, M., and Rodriguez, I. (2009). Formyl peptide receptor-like proteins are a novel family of vomeronasal chemosensors. Nature 459, 574-577. doi: 10.1038/nature08029

Rodolfo-Masera, T. (1943). Sur l'esistenza di un particolare organo olfacttivo nel setto nasale della cavia e di altri roditori. Arch. Ital. Anat. Embryol. 48, 157-212.

Roppolo, D., Ribaud, V., Jungo, V. P., Lüscher, C., and Rodríguez, I. (2006). Projection of the Grüneberg ganglion to the mouse olfactory bulb. Eur. J. Neurosci. 23, 2887-2894. doi: 10.1111/j.1460-9568.2006.04818.x

Salazar, I., and Sánchez-Quinteiro, P. (2003). Differential development of binding sites for four lectins in the vomeronasal system of juvenile mouse: from the sensory transduction site to the first relay stage. Brain Res. 979, 15-26. doi: 10.1016 /S0006-8993(03)02835-X

Salazar, I., and Sánchez-Quinteiro, P. (2009). The risk of extrapolation in neuroanatomy: the case of the mammalian vomeronasal system. Front. Neuroanat. 3:22. doi: 10.3389/neuro.05.022.2009

Salazar, I., Sánchez-Quinteiro, P., Alemañ, N., and Prieto, D. (2008). Anatomical immunohistochemical and physiological characteristics of the vomeronasal vessels in cows and their possible role in vomeronasal reception. J. Anat. 212, 686-697.

Salazar, I., Sánchez-Quinteiro, P., Lombardero, M., and Cifuentes, J. M. (2001). Histochemical identification of carbohydrate moities in the accessory olfactory bulb of the mouse using a panel of lectins. Chem. Senses 26, 645-652. doi: 10.1093/chemse/26.6.645

Schmid, A., Pyrski, M., Biel, M., Leinders-Zufall, T., and Zufall, F. (2010). Grüneberg ganglion neurons are finely tuned cold sensors. J. Neurosci. 30, 7563-7568. doi: 10.1523/JNEUROSCI.0608-10

Schoenfeld, T. A., and Cleland, T. A. (2005). The anatomical logic of smell. Trends Neurosci. 28, 620-627. doi: 10.1016/j.tins.2005.09.005

Shepherd, G. M. (2006). Behaviour: smells, brains and hormones. Nature 439, 149-151. doi: 10.1038/439149a

St John, J. A., Claxton, C., Robinson, M. W., Yamamoto, F., Domino, S. E., and Key, B. (2006). Genetic manipulation of blood group carbohydrates alters development and pathfinding of primary sensory axons of the olfactory systems. Dev. Biol. 298, 470-484. doi: 10.1016/j.ydbio.2006.06.052

Storan, M. J., and Key, B. (2006). Septal organ of Grüneberg is part of the olfactory system. J. Comp. Neurol. 494, 834-844. doi: 10.1002/cne.20858

Suzuki, Y., Takeda, M., Obara, N., Suzuki, N., and Takeichi, N. (2000). Olfactory epithelium consisting of supporting cells and horizontal basal cells in the posterior nasal cavity of mice. Cell Tissue Res. 299, 313-325. doi: $10.1007 / \mathrm{s} 004419900135$ 
Tian, H., and Ma, M. (2008). Differential development of odorant receptor expression patterns in the olfactory epithelium: a quantitative analysis in the mouse septal organ. Dev. Neurobiol. 68, 476-486. doi: 10.1002/ dneu. 20612

Vassar, R., Ngai, J., and Axel, R. (1993). Spatial segregation of odorant receptor expression in the mammalian olfactory epithelium. Cell 74, 309-318. doi: 10.1016/0092-8674(93)90422-M

Wagner, S., Gresser, A. L., Torello, A. T., and Dulac, C. (2006). A multireceptor genetic approach uncovers an ordered integration of VNO sensory inputs in the accessory olfactory bulb. Neuron 50, 697-709. doi: 10.1016/j.neuron.2006.04.033

Walz, A., Feinstein, P., Khan, M., and Mombaerts, P. (2007). Axonal wiring of guanylate cyclase-D-expressing olfactory neurons is dependent on neuropilin 2 and semaphorin 3F. Development 134, 4063-4072. doi: 10.1242/dev.008722

Wekesa, K. S., and Anholt, R. R. (1999). Differential expression of G proteins in the mouse olfactory system. Brain Res. 837, 117-126. doi: 10.1016/S00068993(99)01630-3

Yoon, H., Enquist, L. W., and Dulac, C. (2005). Olfactory inputs to the hypothalamic neurons controlling reproduction and fertility. Cell 123, 669-682. doi: 10.1016/j.cell.2005.08.039
Zancanaro, C. (2014). "Vomeronasal organ: a short history of discovery and an account of development and morphology in the mouse", in Neurobiology of Chemical Communication, Chapter 9, ed C. Mucignat-Caretta (Boca Raton, FL: CRC Press), 285-296. doi: 10.1201/b16511-10

Conflict of Interest Statement: The authors declare that the research was conducted in the absence of any commercial or financial relationships that could be construed as a potential conflict of interest.

Received: 29 May 2014; accepted: 23 June 2014; published online: 14 July 2014. Citation: Barrios AW, Núñez G, Sánchez Quinteiro P and Salazar I (2014) Anatomy, histochemistry, and immunohistochemistry of the olfactory subsystems in mice. Front. Neuroanat. 8:63. doi: 10.3389/fnana.2014.00063

This article was submitted to the journal Frontiers in Neuroanatomy.

Copyright (c) 2014 Barrios, Núñez, Sánchez Quinteiro and Salazar. This is an openaccess article distributed under the terms of the Creative Commons Attribution License (CC BY). The use, distribution or reproduction in other forums is permitted, provided the original author(s) or licensor are credited and that the original publication in this journal is cited, in accordance with accepted academic practice. No use, distribution or reproduction is permitted which does not comply with these terms. 